\title{
Introduction: the narrative
}

\section{Premise and main argument: \\ elaborating the new notion of violence against women's health}

Violence against women (VAW) has been the object of hundreds of studies, pertaining to different areas of research. International law has been one of these areas, the analysis focusing on gender-based violence as a violation of human rights, in particular a violation of the principle of non-discrimination, the prohibition of torture, inhuman or degrading treatment, the right to life, the right to respect for private and family life, and on states' obligations in preventing and combating the widespread phenomenon. VAW is characterised by three distinctive elements: its universality, since the phenomenon is not limited to a specific regional, cultural or religious context; the multiplicity of its forms; and the intersectionality of diverse kinds of discrimination against women. ${ }^{1}$ The then Secretary-General of the United Nations (UN), Kofi Annan, in an in-depth study published in 2006, considered discrimination against women both as a consequence and as a cause of $\mathrm{VAW},{ }^{2}$ in the sense that discrimination against women is at the same time at the very basis of any form of VAW and the outcome of VAW, an obstacle to the achievement of gender equality. ${ }^{3}$

In legal analysis great emphasis has been placed over time on discrimination on the basis of sex, which is often intertwined with other bases such as ethnicity, religion, age and sexual orientation. However, in investigating the phenomenon of violence, an aspect has not been explored sufficiently: violence may severely affect women's health, and in particular reproductive health. As pointed out by the UN Committee on the Elimination of Discrimination against Women (CEDAW Committee), 'gender-based violence is a critical health issue for women.' ${ }^{4}$

Yet VAW does not relate solely to the right to health in consequential terms. As affirmed in 1999 by the then Special Rapporteur (SR) on Violence against Women, its Causes and Consequences, Radhika Coomaraswamy, '[v]iolence against women may occur within the context of reproductive health policy. Violence and violations of women's reproductive health may result either from direct State action, via harmful reproductive policies, or from State failure to meet its core obligations to promote the empowerment of women. ${ }^{5}$ Although 
this argument has not been further developed at the international level, it appears essential in order to build a solid framework for reconceptualising states' obligations in preventing and combating VAW as linked to the right to health and the right to reproductive health.

Using an international law perspective, this book will distil the relationship between violence against women and the right to health, including reproductive health, focusing on the following areas of analysis. Violation of the right to health is a consequence of violence (horizontal dimension), as much as (state) health policies might cause - or create the conditions for - violence against women (vertical dimension). The horizontal dimension aims to consider interpersonal relations, whereas the vertical dimension encompasses state health policies and laws. Both dimensions will be discussed and put to the test throughout the book. The analysis of the relationship will generate one key, innovative idea: violence against women's health (VAWH). This concept is meant to capture the core of the violation of women's rights to health and to reproductive health. Paraphrasing the definition included in the UN General Assembly (UN GA) Declaration on the Elimination of Violence against Women, ${ }^{6}$ violence against women's health constitutes a violation of their right to health and reproductive health.

The idea of VAW is fundamental and well consolidated at the international level; however, despite referring to what I have conceived as the vertical dimension of violence, it mainly focuses on the horizontal, interpersonal dimension. Compared to the concept of VAW, VAWH will be capable of comprehensively grasping the two dimensions of violence affecting women's rights to health and to reproductive health, and will add a new element to the definition: the limitation of women's autonomy, which is absent from the notion of VAW as elaborated at the international level.

The main argument has been built on the paradigm of medicine which has been known since Hippocrates: anamnesis, diagnosis, treatment and prognosis. ${ }^{7}$ The paradigm is a useful tool for constructing the idea of violence against women's health, describing the state of the law and unearthing states' obligations in countering VAWH. The re-conceptualising of states' obligations will start from the international law of state responsibility and will focus on three types of obligation: obligations of result, due diligence obligations and obligations to progressively take steps. The relationship between VAW and women's right to health is a matter of international human rights law. It allows a legal recognition of the harms to their health suffered by female victims/survivors of violence and, at the same time, it reinforces the justiciability of the right to health at the international, regional and domestic levels.

\section{Background}

The relationship between violence against women and the violation of the right to health has not raised as much attention at the international level as 
has the violation of other rights, ${ }^{8}$ in particular civil and political rights. As early as 1980, during the Second World Conference on Women, VAW was considered as a social problem within the ambit of health policies. ${ }^{9}$ However, the relationship has never been overtly encapsulated in an international human rights treaty.

VAW emerged as a human rights issue only in the 1990s, as did the concept of reproductive health. Since then, over the years, many commentators, UN bodies, national and international courts have demonstrated that women's health is a human rights issue, and that reproductive rights are a component of women's right to health. ${ }^{10}$ The UN Convention on the Elimination of All Forms of Discrimination against Women of 1979 (CEDAW) obliges states 'to eliminate discrimination against women in the field of health care' (Article 12(1)), and the CEDAW Committee has interpreted access to health care, including care of reproductive health, as a basic right. ${ }^{11}$ The UN Economic, Social and Cultural Rights Committee (ESCR Committee) acknowledged that the right to the 'highest attainable standard of health' includes 'sexual and reproductive freedoms' in its General Comment (GC) No. 14 (2000), interpreting Article 12 of the International Covenant on Economic, Social and Cultural Rights (ICESCR), and sixteen years later devoted an entire GC, No. 22, to the right to sexual and reproductive health. ${ }^{12}$

Consequences of violence on women's health have been pointed out in communications and concluding observations by the CEDAW Committee, which has also invited states to ensure the adoption of appropriate measures within the health sector. ${ }^{13}$ In 2015, UN human rights experts, the Rapporteur on the Rights of Women of the Inter-American Commission on Human Rights (IACommHR) and the SR on the Rights of Women, and Human Rights Defenders of the African Commission on Human and Peoples' Rights presented a joint statement in which they stressed that 'violence against women, harmful gender stereotypes and multiple and intersectional forms of discrimination based on sex and gender lead to the violation of women's sexual and reproductive health rights. ${ }^{14}$

However, what emerges from existing literature and jurisprudence is that violence affects women's health, a concept that is conceived more as a 'status' than a human right. ${ }^{15}$ In other words, the right to health has been 'absorbed', and indirectly protected, by invoking civil and political rights, such as the prohibition of discrimination, the prohibition of torture, the right to respect for private and family life, and the right to life. For example, domestic violence (DV) and forced sterilisation have been identified by UN bodies as violations of human rights, in particular the right to life, and the prohibition of torture as clarified by the UN Human Rights Committee (HRC) ${ }^{16}$ The reason for what I will call the indirect protection' of the right to health is that the HRC, which has been - at least for the time being - one of the most active bodies at UN level in addressing issues of women's health, is not competent to consider alleged violations of the right to health; this right is not enshrined in the International Covenant on Civil and Political Rights (ICCPR), of which the HRC is the guardian. 
Similarly, at the regional level, the European Court of Human Rights (ECtHR), for example, has only indirectly promoted and protected the right to health of female victims of violence, by applying articles of the European Convention on Human Rights (ECHR) providing for civil and political rights, namely Articles 3 and 8. Regional human rights courts and UN treaty bodies, by means of interpretation, have easily overcome the absence of an express treaty provision on the right to health by applying 'other' human rights. In other words, international and regional jurisprudence has not directly ensured respect for the right to health; rather, it has indirectly promoted the right's content by applying other, more 'justiciable' rights. This affirmation does not reduce the importance of the right to health. The right to health is a human right and so is the right to reproductive health; despite being 'latecomers' among the human rights, that is economic, social, and cultural rights, these rights are human rights, ${ }^{17}$ which create legal obligations on states that ratified the international treaty in which the same rights are enshrined. Furthermore, at the domestic level, the right to health has found wide recognition; more than two-thirds of the world's constitutions make some reference to the right to health, and 'health-related litigation is now commonly pursued in domestic courts. ${ }^{18}$ The right to reproductive health has recently gained momentum, thanks to an increasing number of cases, in particular on abortionrelated issues. For all these reasons, it is time to reconsider the right to health and the right to reproductive health in their relationship with VAW, and put them at the centre of the analysis.

\section{Violence against women: the knowledge so far}

The CEDAW, adopted in 1979, which was aimed at drawing attention to women's inequality, did not include provisions on VAW. ${ }^{19}$ The UN GA adopted in 1985 a resolution in which it invited states to enact measures in response to $\mathrm{DV},{ }^{20}$ and finally, in 1993, it approved a Declaration which addressed VAW as a 'manifestation of historically unequal power relations between men and women' in its preamble. ${ }^{21}$ Article 1 of the Declaration defined VAW as 'any act of gender-based violence that results in, or is likely to result in, physical, sexual or psychological harm or suffering to women, including threats of such acts, coercion or arbitrary deprivation of liberty, whether occurring in public or in private life.' The definition is very similar to the one provided in the year preceding the Declaration by the CEDAW Committee in its pivotal GR No. 19. VAW was conceived as 'violence ... directed against a woman because she is a woman or that affects women disproportionately,' including 'acts that inflict physical, mental or sexual harm or suffering, threats of such acts, coercion and other deprivations of liberty.' ${ }^{22}$ In the Council of Europe Convention on preventing and combating VAW and DV, adopted in 2011 and entering into force in 2014, VAW is defined as 'a violation of human rights and a form of discrimination against women and shall mean all acts of gender-based violence that result in, or are likely to result in, physical, sexual, 
psychological or economic harm or suffering to women, including threats of such acts, coercion or arbitrary deprivation of liberty, whether occurring in public or in private life' (Article 3).

VAW can be considered from five different perspectives. Firstly, it is a form of discrimination against women, both de jure and de facto. ${ }^{23}$ Secondly, VAW is a form of gender-based violence, and 'gender-based violence against women' was precisely the expression chosen by the CEDAW Committee in its most recent GR No. 35, which replaces GR No. 19 of $1992 .{ }^{24}$ Violence against women is based $o n$ gender, on the fact of women being women. Violence does not 'just happen' to occur to women, but it is motivated by 'factors concerned with gender,' such as the need to assert power and control. ${ }^{25}$ The philosopher Susan J. Brison pointed out that the reason why

[i]t is so hard for so many to recognise acts of gender-based violence as such is that if it is an attack by a stranger, it is viewed as 'a random act of violence,' typically by a psychopath, a monster, 'not one of us,' whereas, if it is an attack by a date/ acquaintance/partner/spouse, it is considered to be a crime of passion - motivated by uncontrollable lust or jealous love (that is, if it is considered a crime at all, which, in all too many cases, it is not). That such violence constitutes a violation of women's civil rights is seldom acknowledged. ${ }^{26}$

Thirdly, VAW is a violation of human rights. In GR No. 19, the CEDAW Committee identified the following rights as being infringed by VAW: the right to life; the right not to be subject to torture or to cruel, inhuman or degrading treatment or punishment; the right to equal protection according to humanitarian norms in time of international or internal armed conflict; the right to liberty and security of person; the right to equal protection under the law; the right to equality in the family; the right to the highest attainable standard of physical and mental health; the right to just and favourable conditions of work. ${ }^{27}$ Other rights can be considered, such as the right to privacy, including the right of the abused woman to change surname or to eliminate a surname if by virtue of the marriage she has obtained it, and the rights belonging to the so-called 'third generation' of human rights, such as the rights to peace and to a positive cultural context. ${ }^{28}$ Fourthly, I conceive VAW as an 'umbrella term,' a cluster of offences and harmful behaviours rather than an offence per se. ${ }^{29}$ The element of intent, which characterises offences in criminal law, is therefore not necessary to identify VAW and it is indeed absent from international and regional legal instruments on VAW, including the Council of Europe Istanbul Convention on Preventing and Combating Violence against Women and Domestic Violence (Istanbul Convention). The element of intent is relevant only when it comes to assess individual responsibility for the commission of the specific offences (such as stalking, rape, DV) that can be brought within the terms of the more general framework of VAW. States are responsible for VAW when they violate their obligations to protect the human rights of women who are victims/survivors of violence committed by state and non-state actors. Although not intentionally, states cause or create the conditions 
for VAW, because their systems encourage the perpetuation of patterns of discrimination rooted in the society through policies and laws in the health sector, as I will show, even when these measures are (apparently) adopted for the benefit of women themselves. It has been argued that 'the intention to discriminate may be systematic without being conscious, and thus intentional,' and 'requiring a showing of intent leaves potentially widespread and insidious unconscious discrimination unremedied.' ${ }^{30}$ Fifthly, given the widespread recognition of VAW as a violation of human rights at the international, regional and national levels, it sounds reasonable to enquire whether there exists an international custom prohibiting VAW. The CEDAW Committee, in its landmark GR no. 35 on VAW of 2017, answered in the affirmative. The Committee posited that 'opinio juris and State practice suggest that the prohibition of gender-based violence against women has evolved into a principle of customary international law,' and that 'General recommendation No. 19 has been a key catalyst for this process.' ${ }^{31}$ The question is in fact two intertwined questions, as follows: does an international custom prohibiting gender-based VAW exist? If so, what is the content of this norm? The Committee has proved courageous, and the GR will probably spur the consolidation of a custom to that effect in years to come. For the time being, however, I consider this argument with caution, respectfully contending that international custom has embraced the prohibition of some forms of VAW, but not all of them, especially when violence is committed by the state through the implementation of laws and policies in the field of health. If we do not consider VAW a distinct crime, but rather a broad term including several offences and harmful behaviours that constitute VAW because they are based on gender, then we can separately analyse whether the prohibition of a specific form of violence has achieved the status of customary international law. In this book, as I will try to demonstrate, I might contend that the prohibition of the forms of violence in the horizontal dimension has gradually consolidated as an international custom, but not all forms of violence identifiable in the vertical dimension.

\section{The reasons underlying the choice of the right to health and the right to reproductive health}

In 1994, Mahmoud Fathalla, a professor of obstetrics and gynaecology, and Chair of the World Health Organization (WHO) advisory committee on health research, acknowledged that 'society is not neutral with regard to reproductive rights,' and that in many societies 'the predominant objection against contraceptive use was directed at contraceptive control by women, rather than against contraception itself.' ${ }^{32}$ The same year, Rebecca Cook published an innovative paper commissioned by the WHO on Women's Health and Human Rights, in which she emphasised the 'pervasive neglect of women's health. ${ }^{33}$ In 1995, Aart Hendriks contended that 'woman's right to sexual and reproductive health is not only threatened by current expressions of deep-rooted, harmful practices - including 
sexual violence against women and girls, forced marriage, and female genital mutilation - but is also challenged by progress in reproductive medicine. ${ }^{34}$ It is noteworthy that almost twenty years after these outstanding contributions, Erin Nelson, in her remarkable work on the notion of reproductive autonomy, reflected on the fact that the 'history of reproductive regulation is a history of attempting to enforce a traditional view of women as child-rearers. ${ }^{35}$ In 2016, the working group on the issue of discrimination against women in law and in practice, established at UN level, confirmed this view, by stating in its report that 'women's bodies are instrumentalized for cultural, political and economic purposes rooted in patriarchal traditions,' and 'instrumentalization occurs within and beyond the health sector and is deeply embedded in multiple forms of social and political control over women. ${ }^{36}$

In appreciating the two dimensions at the core of the book - the violation of the right to health is a consequence of violence (horizontal dimension) as much as (state) health policies might be a cause of violence against women (vertical dimension) - which allow me to conceive the new idea of VAWH, the functional relationship existing between VAW and the rights to health and reproductive health should be emphasised. VAW has already been analysed from a human rights perspective, focusing, for example, on non-discrimination and the prohibition of torture, cruel, inhuman or degrading treatment, or punishment. ${ }^{37}$ The right to health and the right to reproductive health are also worth exploring in detail, however, for the innovative contribution they can make to the analysis of VAW. First, these human rights - I will conceive them as human rights, and not as mere status - are always impaired by episodes of violence, as much as in all cases VAW is a form of discrimination against women. Secondly, these rights belong to the category of economic, social and cultural rights, which have been deemed less 'justiciable' than other rights. It is time to debunk the myth by demonstrating the justiciability of the right to health and the right to reproductive health as linked to violence against women, and to encourage the inclusion of these rights in international legal instruments. ${ }^{38} \mathrm{~A}$ focus on economic, social and cultural rights would be extremely useful to empower women and to challenge the stereotyped visions of the role women play in society. ${ }^{39}$ It is striking indeed that the Council of Europe's pivotal Istanbul Convention, adopted in 2011 and entered into force in 2014, contains just one provision concerning the right of the victim to receive compensation after suffering from a severe impairment of health. ${ }^{40}$ As correctly pointed out by Cheryl Hanna:

we legal scholars have been missing something. While our medical colleagues have done tremendous work in documenting the health effects of partner violence, to a large extent, legal scholars have been unsure exactly how physical and reproductive health, in particular, ought to factor into law. But, if we start with the premise that the right to health ... is a basic human right, then we can begin to understand how including health in our arguments about affirmative state duties to end gendered violence can provide another perspective and another tool to persuade the powers that be to prioritize eliminating gendered violence. ${ }^{41}$ 
Thirdly, the focus on these two rights allows me to reflect on the public/private divide. Let us consider population policies. The anti-natalist programmes of many governments have concentrated on the 'excessively' fertile bodies of women belonging for example to ethnic minorities, and accordingly they have 'used language, made recommendations, and provided funds for activities that, in sum, suggest coercion.' ${ }^{42}$ Similarly, pro-natalist policies have employed coercive methods. The criminalisation of abortion which has aimed to put 'women, doctors, and other facilitators in danger and sometimes behind bars,' and selective restrictions on contraception, both legal and administrative, 'often in the name of women's health,' are just two examples. ${ }^{43}$ Here lies a challenging paradox. States have not traditionally intervened in matters related to DV, since it was considered as pertaining to the 'private' sphere, until the affirmation of VAW as a form of discrimination against women and a violation of human rights in the 1990s. States did however - and do in many cases - interfere with women's 'private' choices concerning their reproductive health in the name of population policies, which have invariably been perceived as more relevant than the individual's autonomy. Population policies also demonstrate the structural nature of discrimination against women, whose rights can be sacrificed for other purposes defined by state (male) authorities. Here this book critically reviews and challenges the traditional distinction private $=$ women, public $=$ men,${ }^{44}$ which is a true picture if we consider the political public sphere as populated by men and the state as male subject, but does not capture in its entirety the complexity of the relationship which is at the core of this book. I will therefore argue that the domestic environment also is male and that this view has historically justified the absence of interference by states in cases of domestic violence. ${ }^{45}$ Rhonda Copelon interestingly argued that "patriarchal ideology also constructed the private sphere of family and intimate relations as off-limits to State intervention even where violence was concerned,' and that 'by adopting a hands-off policy, the public sphere supported the violent exercise of power in the so-called private sphere.' ${ }^{46}$ This view supports my choice to concentrate on women's rights to health and reproductive health. They have been neglected because the private sphere has been conceived as male, and so domestic violence has been excluded from state interference and women's health regarded as not suitable for leaving to women's autonomy only. I contend that the right to health, including sexual and reproductive health, is always at stake in episodes of VAW - in terms of both immediate and lasting consequences - and that an analysis from this perspective is much more gender-sensitive, since, on one hand, it takes into consideration the 'gendered experiences that affect [women's] health, ${ }^{47}$ and on the other hand it implies - in particular with regard to reproductive health - the 'ability' to exercise reproductive autonomy, ${ }^{48}$ in other words, women's right to decide. In this book I will use the expression 'right to reproductive health,' as chosen by the Committee on ESCR in its GC No. 22. 


\section{Why human rights and why women's rights?}

As I explained, I will consider health and reproductive health as human rights, and not as mere status as envisaged by the WHO. It should be stressed at the outset that human rights law is not devoid of criticism. It is not the purpose here to review all the theories existing in the field - this analysis would go well beyond the scope of my research - but to admit that it is impossible not to mention the limits human rights have shown. ${ }^{49}$ For the purpose of my book, it is worth spending a few words on the universality issue, which is at the core of the debate on human rights, and in particular of women's rights. Just consider the debate on whether human rights are universal or relative, and the role of culture, while dealing, for example, with female genital mutilation/cutting (FGM/C). Are these practices acceptable because they find their basis in culture? Is the prohibition of these practices at the international level a new form of Western imperialism $?^{50}$ The concept of 'Asian values' has been coined for the Asian continent, ${ }^{51}$ but does it mean that human rights law is not universal? The debate is too complex to be dealt with in few lines. ${ }^{52}$

Practices that significantly impair a woman's or a girl's bodily integrity have been condemned not only by European countries, but also by countries where $\mathrm{FGM} / \mathrm{C}$, for example, is tolerated, and even encouraged, by local communities. ${ }^{53}$ One should bear in mind that the victims are usually girls who are too young to express consent to undergo the practice. Even though the practice is transmitted from mother to daughter and is accepted within a community, even if it is perpetrated and supported by women, FGM/C is VAW, as I have argued elsewhere, ${ }^{54}$ and it constitutes a violation of human rights, as well as a form of discrimination against women. Moreover, Chinkin and Charlesworth pointed out that what is striking is that 'culture is much more frequently invoked in the context of women's rights than in any other area. ${ }^{55}$ In GC No. 21, the ESCR Committee argued that 'applying limitations to the right of everyone to take part in cultural life may be necessary in certain circumstances, in particular in the case of negative practices, including those attributed to customs and traditions, that infringe upon other human rights. ${ }^{56}$

Nonetheless, the condemnation of practices such as FGM/C cannot be blind. Other practices widespread in European and American countries, supported by similar stereotyped views of the role of women in society, must be assessed from the perspective of human rights law. Accordingly, this book will explore whether and to what extent genital cosmetic surgery can be compared to $\mathrm{FGM} / \mathrm{C}$, in particular in terms of the consent expressed by the girl/woman to the practice. ${ }^{57}$

As I anticipated, VAW is universal, rooted in every society and manifests itself in different forms. In European countries, 'honour' is still a 'mitigating factor' for certain forms of violence - not necessarily under the law but surely within society - and the 'behaviour' of a female victim of rape or sexual abuses determines whether or not she deserves compassion or dishonour. ${ }^{58}$ 
It can be argued that human rights law has also failed to take into consideration women's specific needs, by 'essentialising the category of women and the attendant privileging of the perspectives of First World women (or some of them) while failing to reflect the multiple factors that interact to constitute violations around the world. ${ }^{59}$ However, the reasoning can go a bit further. In an inspiring book on sex-selective abortions affecting women of Indian origin in India and the United States, Sital Kalantry used the word 'decontextualisation' to contend that universalistic perspectives are limited in evaluating bans on practices that immigrants bring from one country to another. ${ }^{60}$ In her view, sex-selective abortion, which is a form of severe discrimination against women and girls in India, cannot be seen in the same way in the USA, where the practice, far from being widespread (as data have shown), has been condemned by anti-abortionist associations for limiting women's autonomy. Context, which is not merely geographical but also social and economic, has therefore a role to play. ${ }^{61}$ This book suggests the expression 'contextualised universalism' as appropriate to protect women's rights while taking into account the context in which violence is perpetrated. I argue that the debate shifts from the dichotomy universal-relative to the analysis of different grounds of discrimination. In other words, it is not a matter of which culture is at the basis of the violation of women's rights, but rather across which grounds - gender, ethnicity, class, social and economic conditions - discrimination is perpetrated. It has been contended that 'neither a claim to universal principles nor a claim to cultural relativism adequately addresses the global aspect of gendered violence.' ${ }^{62}$ Considering different grounds for discrimination, as interestingly argued, 'will strengthen our capacity to realise the full humanity and equality of women - and other genders - everywhere. ${ }^{63}$ This perspective permits us to overcome the differences between approaches, by capturing the meaning of discrimination against women, and against other genders as well. It also emphasises the aspect of intersectionality, which I will discuss further in the book. The international community has indeed started, slowly, 'to explore ways to analyse women's human rights that do not represent women as a monolithic category,' meeting the request of feminists from the global South. ${ }^{64}$

So far, I have discussed women's rights. What about those of other genders? Dianne Otto overcomes the duality masculine/feminine by conceiving sex and gender as a fully social and performative category, which implies that international human rights law can reconceive sex/gender as 'a fluid conception that has multiple forms of expression and identification. ${ }^{65}$ By conceiving sex and gender as a dichotomy, women have always been depicted as vulnerable and in need of protection, the object of international treaties which only focus on their weaknesses and therefore reproduce the 'maleness' of the universal subject of international human rights law. ${ }^{66}$ The approach has evolved over time, thanks to the work of UN treaty bodies and the increasing focus on women as agents of change; however, one should keep in mind the beginning of the debate before reflecting on its evolution. 
Having said that, this book concentrates on women and girls because they are, as data demonstrates worldwide, the majority of victims/survivors of violence. This is a way, not to victimise women but rather to acknowledge the discrimination which is rooted in society. VAW is extremely entrenched in society and in history. This is clear if we consider, for example, the founding myth of Europe: a rape. ${ }^{67}$ To acknowledge the structural nature of VAW does not mean excluding episodes of violence committed against other genders, but rather emphasising a dramatic trait of every society. If governments still decide to appoint mostly male ministers, except maybe one or two; if it is still possible to object to women having freedom to choose regarding their body; then there is still room to write and to reflect on the topic. It is a matter of feminist studies, and human rights.

\section{Perspective: the Hippocratic medical paradigm}

Existing literature has extensively analysed the phenomenon of VAW and has commented on cases decided by regional and national courts, and by UN treaty bodies, regarding women's health and reproductive rights. This study needed a conceptual model, which I found in the medical paradigm: anamnesis, diagnosis, treatment and prognosis. This might seem a simplistic scheme, which only takes into account part of the complexity of 'illness' (there is more than one disease; the patient's reaction can differ according to the circumstances, etc.), but it turns out to be a useful backbone for the main argument. This choice draws heavily on the natural link between health and the field of medicine, but is also dictated by the fact that it has never been explored in these terms. This paradigm is a descriptive one, because it allows a clear systematisation of the different aspects of the research according to a plausible and logical structure. It is also a building paradigm, because through distillation of the relationship between VAW and the rights to health and to reproductive health it conceives a new notion, VAWH, which leads to the reconceptualisation of states' obligations.

The medical paradigm composed of anamnesis, diagnosis, treatment and prognosis owes its existence to Hippocrates. Hippocrates of Coen is the name given to the 400BCE author of the Hippocratic corpus of writings which defined the school of medicine that bears his name. His life and his works are surrounded in an aura of mystery. As stressed by Edelstein, 'the belief has been current that none of the so-called Hippocratic writings could be ascribed with any certainty to Hippocrates himself.' ${ }^{68}$ The Corpus Hippocraticum refers to 58 writings which introduced both a theory of disease and a complete description of diagnostics and treatment ('On Fistulas,' 'On Fractures,' 'On Injuries of the Head,' 'The Book of Prognostics,' etc.). ${ }^{69}$ Greek medicine differed from previous practices in its search for the true causes of health. Empirical observation was therefore necessary in order to understand the illness and its course. 
Anamnesis consists in the act of remembering, in the reconstruction of the medical history of the patient, which goes beyond mere observation of the body. As outlined by Leavy:

At least as early as Hippocrates' time, it was recognised that human nature is not limited to that which can be observed by the examination of the body. Human nature is historical, and the first part of the examination, then as now, consisted of a history, an anamnesis as it is called, which means a calling to mind of a person's past. Nor did Hippocrates make this anamnesis just a listing of earlier symptoms or earlier diseases; it is also an account of experiences so far as they are thematically pertinent. ${ }^{70}$

Plato referred to anamnesis as 'recollection', although his thought has never been linked to medical history. In his introduction of the theory of recollection in the Meno, 81d, it is written that:

[a]s the whole of nature is akin, and the soul has learned everything, nothing prevents a man, after recalling one thing only - a process men call learning - discovering everything else for himself, if he is brave and does not tire of the search; for searching and learning, are, as a whole, recollection (anamnesis).$^{71}$

In other words, anamnesis has a technical meaning within Plato's epistemology. It is the process that permits the remembering of Ideas/Forms through the sensible world.

Diagnosis can be defined as the 'identification of the nature of an illness or other problem by examination of the symptoms. ${ }^{72}$ Diagnosis has been considered to provide the 'true state of the patient,' but this affirmation is problematic, since it is 'a construct of medical knowledge and reasoning methodology applied in clinical decision-making. ${ }^{73}$ Accordingly, Sadegh-Zadeh has distinguished between two terms: diagnostics, that is the investigation into the patient's health conditions, and diagnosis, which is the outcome of the former. ${ }^{74}$ After making a diagnosis, a physician would proceed with treatment, in order to restore the balance that the illness has disrupted, and with prognosis. In Hippocratic medicine, as in every kind of medicine, prognosis is 'the prediction of the outcome of the disease, as well as its fluctuations and transmutations. ${ }^{75}$ If the physician 'knows what course the disease will take, he is also better able to prepare for what is to come.' 76 The 'place of truth' does not reside in the past (anamnesis), but rather in the future (prognosis), where it is possible to assess the appropriateness of the treatment and of the interpretative hypothesis from which it originates. ${ }^{77}$

Against this backdrop, it is necessary to ask whether this paradigm can be used in other fields of study. In the book The Therapy of Desire, Martha Nussbaum used the paradigm to study the schools of philosophy that developed in the Hellenistic period. Reflecting on Hellenistic ethics, Nussbaum identified three closely related ideas in the therapeutic investigative process. ${ }^{78}$ The first two ideas are relevant here, since they concern 'a tentative diagnosis of disease, of factors, especially socially taught beliefs, that are most prominent in preventing people from living well,' and 'a tentative norm of health: a conception (usually general 
and to some degree open-ended) of the flourishing and complete human life. ${ }^{79}$ Thus the ideas elaborated in Hellenistic thought are well suited to describe all aspects of human life.

In the field of international studies, the sociologist Johan Galtung applied the Hippocratic paradigm to the peaceful resolution of disputes between states in his famous work Peace by Peaceful Means. ${ }^{80} \mathrm{He}$ argued that peace studies 'have much to learn from the paradigm,' and that 'much thought, speech and action in the field of violence/peace diagnoses violence, but then only as direct and physical, and mainly the acute case. ${ }^{81}$ He interestingly contended that the prognosis is that 'unless treated, violence will be repeated.' With regard to therapies, the 'so what, what are you going to do about it?', Galtung was convinced that 'we need maps of the social reality in which violence and peace can unfold. ${ }^{92}$ The question was therefore the following: how can peace researchers do peace work (therapy)? Accordingly, he elaborated different peace research paradigms.

The challenge this book faces is to build the new concept of VAWH. The book will not consider the woman as unique patient, because I believe that depicting women as vulnerable subjects does not help in eradicating VAW. Women are agents of change as much as they are victims when, for example, they bring their cases before domestic or regional courts, or before international bodies. Therefore, I contend in the diagnosis that VAWH is an illness that, by personally affecting individuals, affects the entire society. VAW is indeed a 'public health' concern, as stressed by the WHO; ${ }^{83}$ so is VAWH. The anamnesis will not consider the personal experiences and the emotions of women, but it will be conducted from an international law perspective. Mutatis mutandis, empirical observation and the act of remembering entail, from an international legal point of view, the analysis of state practice and of international, regional and domestic jurisprudence in order to find common trends and critically discuss the interpretation given to legal instruments in force.

The framework built in the first part of this book will pave the way for a reconceptualising of states' obligations under international law, which constitutes the treatment. As recently posited by the ESCR Committee in its GC on the right to sexual and reproductive health, 'States parties have a core obligation to ensure, at the very least, minimum essential levels of satisfaction of the right to sexual and reproductive health. In this regard, States parties should be guided by contemporary human rights instruments and jurisprudence, as well as the most current international guidelines and protocols established by United Nations agencies, in particular WHO and the United Nations Population Fund. ${ }^{94}$

The strength of my reasoning lies in the fact that both dimensions, the horizontal and the vertical as conceived in this book, can be unified while discussing the reconceptualising of states' obligations. In both dimensions, I will contend that - and provide examples of how - states bear legal obligations of result, due diligence and to progressively take steps. I will show that the difference between the two dimensions does not concern the 'type' of the obligations, but rather the fact that obligations 'specialise' along one or other of the two explored dimensions. 


\section{Structure of the book}

The first chapter contains the anamnesis and is based on the analysis of selected jurisprudence of regional human rights and domestic courts, and of the quasi-jurisprudence of UN treaty bodies, related to both dimensions, focusing on the applicants, the direct or indirect application of the rights to health and reproductive health, the relevance of women's health in the analysis and reparations. The second chapter, the diagnosis, draws on the precedent and conceptualises the notion of VAWH, a new socio-legal notion, which will prove capable of encompassing both the horizontal and the vertical dimensions of violence. In this chapter I will construct the notion of VAWH as a form of discrimination against women, and a violation of the rights to health and to reproductive health. I will then reflect on autonomy and consent, and I will elaborate a human rights-based notion of autonomy as related to VAWH. In the third chapter, I will delve into treatment, which, in my view, is the reconceptualising of states' obligations. I will start from basic notions of international law, before finding the most suitable category to apply to VAWH. I will provide examples of states' obligations of result, due diligence and to progressively take steps putting both dimensions under the same umbrella. Finally, as prognosis I will provide some concluding remarks, challenging, for the last time, my paradigm, and wondering whether it is not international law itself that is the ultimate cause of VAWH.

\section{Notes}

1 United Nations (UN) Economic and Social Council (ECOSOC), Integration of the Human Rights of Women and the Gender Perspective: Violence against Women towards an Effective Implementation of International Norms to End Violence against Women, Report of the Special Rapporteur (SR) on Violence against Women (VAW), its causes and consequences, Yakin Ertürk, E/CN.4/2004/66, 26 December 2003, pp. 16-17. For a discussion of intersectionality, see chapter 1 , 'Involuntary sterilisation: Context and legal background'.

2 UN General Assembly (UN GA), Sixty-first session, Advancement of women. In-depth study on all forms of violence against women. Report of the Secretary-General, 6 July 2006, para. 377.

3 See C. Chinkin, 'Violence against women', in M.A. Freeman, C. Chinkin and B. Rudolf (eds), The UN Convention on the Elimination of All Forms of Discrimination against Women (Oxford: Oxford University Press, 2012) 443, p. 446. See also C. Bunch, 'Transforming human rights from a feminist perspective', in J. Peters and A. Wolper (eds), Women's Rights, Human Rights, International Feminist Perspectives (New York, London: Routledge, 1995) 11, p. 15.

4 Views of 27 November 2012, S.V.P. v. Bulgaria, Communication No. 31/2011, para. 9.10 . 
5 'Integration of the Human Rights of Women and the Gender Perspective Violence against Women', E/CN.4/1999/68/Add.4, 21 January 1999, para. 44.

6 A/RES/48/104, 20 December 1993.

7 On Hippocrates and his method, see J. Jouanna, Hippocrate: Pour une archéologie de l'école de Cnide (Paris: Les Belles Lettres, 1974), and P. Van der Eijk, Medicine and Philosophy in Classical Antiquity: Doctors and Philosophers on Nature, Soul, Health and Disease (Cambridge: Cambridge University Press, 2005), p. 45ff.

8 On VAW, hundreds of articles and books have been written. A complete bibliography on women's rights (including violence against women) until 1995 is given in R. Cook and V. Oosterveld, 'A selected bibliography of women's human rights', The American University Law Review 44 (1995) 1429, and, until 2012 with specific regard to the UN Convention, M. Freeman, C. Chinkin and B. Rudolf (eds), The UN Convention on the Elimination of All Forms of Discrimination against Women (Oxford: Oxford University Press, 2012), p. 689 (Convention henceforth referred to as CEDAW). As reference articles and books, inter alia: S. Brownmiller, Against our Will. Men, Women and Rape (New York: Fawcett Columbine, 1975); H. Charlesworth and C. Chinkin, 'Violence against women: a global issue', in J. Stubbs (ed.), Women, Male, Violence and the Law (Sydney: Institute of Criminology, 1994) 13; R.J. Cook (ed.), Human Rights of Women: National and International Perspectives (Philadelphia: University of Pennsylvania Press, 1994); R. Copelon, 'Recognizing the egregious in the everyday: domestic violence as torture', Columbia Human Rights Law Review 25 (1994) 291; C. MacKinnon, 'On torture: a feminist perspective on human rights', in K.E. and Paul Mahoney (eds), Human Rights in the Twenty-First Century: A Global Challenge (The Hague: Martinus Nijhoff, 1993) 21; K. Dawn Askin and D.M. Koenig, Women and International Human Rights Law, vol. 1 (New York: Transnational Publishers, Inc., 1999); C. Chinkin and H. Charlesworth, The Boundaries of International Law: A Feminist Analysis (Manchester: Manchester University Press, 2000); S. Engle Merry, 'Constructing a global law - violence against women and the human rights system', Law and Social Inquiry 28 (2003) 941; S. Engle Merry, Human Rights and Gender Violence (Chicago: University of Chicago Press, 2006); C. Benninger-Budel (ed.), Due Diligence and its Application to Protect Women from Violence (The Hague: Brill, Nijhoff, 2008); A. Byrnes and E. Bath, 'Violence against women, the obligation of due diligence, and the optional protocol to the Convention on the Elimination of All Forms of Discrimination against Women - recent developments', Human Rights Law Review 8 (2008) 517; B. Meyersfeld, Domestic Violence and International Law (Oxford: Hart Publishing, 2012); Chinkin, 'Violence against women'; A. Edwards, Violence against Women under International Human Rights Law (Cambridge: Cambridge University Press, 2010).

9 Report of the World Conference of the UN Decade for Women, Copenhagen, 1980, A/CONF.94/35, Resolution 5, para. 141(f). A comment appears in Chinkin, 'Violence against women', p. 445.

10 On reproductive and sexual rights, see the outstanding book by R.J. Cook, B.M. Dickens and M.F. Fathalla (eds), Reproductive Health and Human Rights: Integrating Medicine, Ethics, and Law (Oxford: Oxford University Press, 2003). See also, among others, for a general overview regarding legal issues, Cook, Human Rights of Women; R. Cook, 'International human rights and women's reproductive health', Studies in Family Planning 24 (1993) 73; M. Scheinin, 'Sexual rights as human rights - protected under existing human rights treaties?', Nordic Journal of International Law 67 (1998) 17; I.L. 
Feitshans, 'Is there a human right to reproductive health?', Texas Journal of Women and the Law 8 (1998-9) 93; D. Bogecho, 'Putting it to good use: the international Covenant on Civil and Political Rights and Women's Rights to Reproductive Health', Review of Law and Women's Studies 13 (2003-4) 229; J.M. Joachim, Gender Violence and Reproductive Rights (Washington DC: Georgetown University Press, 2007); S. Correa, R. Petchesky and R. Parker (eds), Sexuality, Health and Human Rights (Abingdon: Routledge, 2008); S. Deller Ross, Women's Human Rights: The International and Comparative Law Casebook (Philadelphia: University of Pennsylvania Press, 2008); L. Reichenbach and M.J. Roseman (eds), Reproductive Health and Human Rights (Philadelphia: University of Pennsylvania Press, 2009); A. Kulczycki (ed.), Critical Issues in Reproductive Health (Dordrecht, Heidelberg, New York, London: Springer, 2014). Also relevant are the articles published in Health and Human Rights Journal (among others, see D. Uberoi and M. De Bruyn, 'Human rights versus control over women's reproductive self-determination', Health and Human Rights 15 (2013) 161), and the World Health Organization (WHO) report on Global and regional estimates of violence against women: prevalence and health effects of intimate partner violence and non-partner sexual violence, Geneva, 2013.

Also relevant are the articles published in Health and Human Rights Journal (among others, see D. Uberoi and M. De Bruyn, 'Human rights versus control over women's reproductive self-determination', Health and Human Rights 15 (2013), p. 161), and the World Health Organization (WHO) report on Global and regional estimates of violence against women: prevalence and health effects of intimate partner violence and non-partner sexual violence, Geneva, 2013.

11 General Recommendation (GR) No. 24 (1999) on Article 12 of the Convention, Women and Health (CEDAW Committee). See also R.J. Cook and V. Undurraga, 'Article 12', in Freeman et al., The UN Convention, 311, p. 317.

12 General Comment (GC) No. 14 (2000) on the Right to the Highest Attainable Standard of Health and GC No. 22 (2016) on Sexual and Reproductive Health (UN Economic, Social and Cultural Rights (ESCR) Committee). See also, although it is not my purpose to provide an analysis here, GC No. 36 (2018) on the Right to Life (Human Rights Committee - HRC) which reflects on abortion at para. 8 .

13 See, for the cases before 2010, Cook and Undurraga, 'Article 12', and, among recent examples, the concluding observations of the CEDAW Committee on Slovenia, 23 November 2015, p. 11, where the Committee found that cuts in the health budget and the new requirement for women to cover 20 per cent of the cost of sexual and reproductive health services have negative consequences for women's health.

14 Joint Statement of 24 September 2015, available at www.ohchr.org/SP/NewsEvents/ Pages/DisplayNews.aspx?NewsID=16490\&LangID=E (accessed 15 October 2019).

15 On the right to health see J. Tobin, The Right to Health in International Law (Oxford: Oxford University Press, 2012) and bibliography there included. See also M. Bèlanger, 'Réflexions sur la réalité du droit international de la santé', Revue québécoise de droit international II (1985) 19; A. Hendriks, 'The right to health', European Journal of Health Law 1 (1994) 187; B. Toebes, 'Towards an improved understanding of the international human right to health', Human Rights Quarterly 21 (1999) 661; A. Hendriks, 'The close connection between classical rights and the right to health, with special reference to the right to sexual and reproductive health', Medicine and Law 18 (1999) 225; B. Toebes, R. Ferguson, M.M. Markovic and O. Nnamuchi (eds), 
The Right to Health: A Multi-Country Study of Law, Policy and Practice (The Hague: Asser Press, 2014); P. Hunt (author of numerous publications and reports while he was UN SR on the right to health), 'Interpreting the international right to health in a human rights-based approach to health', Health and Human Rights 18 (2016) 109; T. Murphy, Health and Human Rights (Oxford and Portland, OR: Hart Publishing, 2013); M.A. Grodin, D. Tarantola, G.J. Annas and S. Gruskin (eds), Health and Human Rights in a Changing World (New York, London: Routledge, 2013); L. Forman, L. Caraoshi, A.R. Chapman and E. Lamprea, 'Conceptualizing minimum core obligations under the right to health: how should we define and implement the "morality of the depths", International Journal of Human Rights (2016) 531; C. Napoli, 'Le droit des femmes à la santé', in M. Jänterä-Jareborg and H. Tignoudja (eds), Women's Rights and the Elimination of Discrimination (The Hague: Brill Nijhoff, 2016) 555; J. Tasioulas, The Minimum Core of the Human Right to Health (Washington DC: World Bank, 2017), available at https://openknowledge.worldbank.org/handle/10986/29143.

16 Bogecho, 'Putting it to good use', p. 247ff. Among the views adopted by UN committees, see for example the case K.L. v. Peru, of 22 November 2005, Communication No. $1153 / 2003$. On forced and involuntary sterilisation, see the comprehensive report of the WHO, Eliminating Forced, Coercive and Otherwise Involuntary Sterilization. An Interagency Statement (Geneva, 2014).

17 On the importance of distinguishing the right to health from the 'interest in health' see the recent article by J. Tasioulas, 'Saving human rights from human rights law', Vanderbilt Journal of Transnational Law 52 (2019) 1167. See also the previous work by J. Tasioulas and E. Vayena, 'The place of human rights and the common good in global health policy', Theoretical Medicine and Bioethics 37 (2016) 365, p. 370 .

18 B. Saul, D. Kinley and J. Mowbray, The International Covenant on Economic, Social and Cultural Rights. Commentary, Cases and Materials (Oxford: Oxford University Press, 2014), pp. 1061-2.

19 D. Otto, 'Women's rights', in D. Moeckli, S. Shah and S. Sivakumaran (eds), International Human Rights Law (Oxford: Oxford University Press, 3rd edn, 2018) 317. The author identifies four limits of the Convention: the comparison between men and women, the lack of reference to VAW, the assumption of normative married heterosexuality and 'the very limited acknowledgement of multiple and intersectional forms of discrimination.'

20 A/RES/40/36 (1985).

21 A/RES/48/104, preamble.

22 GR No. 19, A/47/38 (1992), CEDAW Committee, para. 6.

23 The 2011 (Council of Europe) Istanbul Convention on Preventing and Combating Violence against Women and Domestic Violence (Istanbul Convention) promotes the 'realisation of de jure and de facto equality between women and men' as 'a key element in the prevention of violence against women' (preamble).

24 GR No. 35 on gender-based violence against women, updating GR No. 19, 14 July 2017, CEDAW/C/GC/35.

25 Chinkin, 'Violence against women', p. 452.

26 S.J. Brison, 'Justice and gender-based violence', Revue international de philosophie 67:3 (2013) 263.

27 GR No. 19, para. 7. 
28 See the Protocol to the African Charter on Human and People's Rights on the Rights of Women in Africa (Maputo Protocol), 11 July 2003, Articles 16 and 17.

29 See, in more detail, S. De Vido, Donne, violenza e diritto internazionale. La Convenzione di Istanbul del Consiglio d'Europa del 2011 (Udine, Milan: Mimesis, 2016).

30 A.X. Fellmeth, Paradigms of International Human Rights Law (Oxford: Oxford University Press, 2016), p. 162 and p. 178. Contra, R. Sifris, Reproductive Freedom, Torture and International Human Rights (London and New York: Routledge, 2014), p. 128, contending that when 'harms are clearly foreseeable,' it is difficult to argue 'that they are not intended.'

31 GR No. 35, para. 2. See a comment in S. De Vido, 'The prohibition of violence against women as customary international law? Remarks on the CEDAW General Recommendation No. 35', Diritti umani diritto internazionale 2 (2018) 379.

32 M.F. Fathalla, 'The impact of reproductive subordination on women's health family planning services', American University Law Review 44 (1994-5) 1179, pp. 1181-2.

33 R. Cook, Women's Health and Human Rights (Geneva: WHO, 1994), p. 5.

34 A. Hendriks, 'Promotion and protection of women's right to sexual and reproductive health under international law: the economic Covenant and the women's Convention conference on the interventional protection of reproductive rights: the right to health', American University Law Review 44 (1995) 1123, p. 1127.

35 E. Nelson, Law, Policy, and Reproductive Autonomy (Oxford, Portland, OR: Hart Publishing, 2013), p. 66.

36 Report of the working group on the issue of discrimination against women in law and in practice, A/HRC/32/44, 8 April 2016, para. 18.

37 See, for example, the analysis in A. Edwards, Violence against Women under International Human Rights Law (Cambridge: Cambridge University Press, 2011).

38 On justiciability, see M.K. Addo, 'The justiciability of economic, social and cultural rights', Commonwealth Law Bulletin 14 (1988) 1425; M.K. Addo, 'Justiciability re-examined', in R. Beddard and D.M. Hill (eds), Economic, Social and Cultural Rights: Progress and Achievement (London: Macmillan, 1992) 93. See also $\mathrm{K}$. Tomasevski, 'Justiciability of economic, social and cultural rights', ICJ Review (1995) 203; J.K. Mapulanga-Hulston, 'Examining the justiciability of economic, social and cultural rights', The International Journal of Human Rights 6 (2002) 29, p. 36; M.J. Dennis and D. P. Steward, 'Justiciability of economic, social and cultural rights: should there be an international complaints mechanism to adjudicate the rights to food, water, housing and health?', American Journal of International Law 98 (2004) 462; C. Chinkin, The Protection of Economic, Social and Cultural Rights Post-Conflict, paper of 2007, p. 33 available at www2.ohchr.org/english/issues/ women/docs/Paper_Protection_ESCR.pdf; L. Forman, 'Justice and justiciability: advancing solidarity and justice through South Africans' right to health jurisprudence', Medicine and Law 27 (2008) 661.

39 See C. Chinkin and S. Wright, 'The hunger trap: women, food and self-determination', Michigan Journal of International Law 14 (1992-3) 262, p. 312.

40 I am referring to Article 30 of the Convention. On the Istanbul Convention, see De Vido, Donne, Violenza, and R. McQuigg, The Istanbul Convention, Domestic Violence and Human Rights (Abingdon: Routledge, 2017). 
41 C. Hanna, 'Health, human rights, and violence against women and girls: broadly redefining affirmative state duties after Opuz v. Turkey', Hastings International \& Comparative Law Review 34 (2011) 127, p. 136. She was referring to the thoughts of Virginia A. Leary, 'The right to health in international human rights law', Health and Human Rights 1:1 (1994) 24.

42 R. Solinger and M. Nakachi, 'Introduction', in R. Solinger and M. Nakachi (eds), Reproductive States (Oxford: Oxford University Press, 2016) 1, p. 21.

43 Solinger, Nakachi, 'Introduction', pp. 21-2.

44 See C. Pateman, 'Critiques of the public private dichotomy', in S.I. Benn and G.F. Gaus (eds), Public and Private in Social Life (New York: St Martin's Press, $1983)$ 281; C. Pateman, The Sexual Contract (Stanford, CA: Stanford University Press, 1988); S. Moller Okin, Women in Western Political Thought (Princeton, NJ: Princeton University Press, 1988). See also Meyersfeld, Domestic Violence, p. 100; H. Charlesworth, C. Chinkin and S. Wright, 'Feminist approaches to international law', American Journal of International Law 85 (1991) 613, p. 615; R. Gavison, 'Feminism and the public/private distinction', Stanford Law Review 45 (1992) 1; C. Romany, 'State responsibility goes private: a feminist critique of the public/private distinction in international human rights law', in Cook, Human Rights of Women, 85; K. Engle, 'International human rights and feminism: when discourses meet', Michigan Journal of International Law 13 (1991-2) 5, p. 17; D. Sullivan, 'The public/private distinction in international human rights law', in J. Peters and A. Wolper (eds), Women's Rights, Human Rights: International Feminist Perspectives (New York, Routledge, 1995) 103, E. Wicks, The State and the Body (Oxford and Portland, OR: Hart, 2016), p. 16ff.

45 S. Wright, 'Women and the global economic order: a feminist perspective', American University International Law Review 10 (1995) 861, p. 867.

46 R. Copelon, 'Gender violence as torture: the contribution of CAT General Comment no. 2', New York City Law Review 11 (2008) 229, p. 237.

47 R.C. Cook, 'Gender, health and human rights', in M. Grodin, D. Tarantola, G. Annas and S. Gruskin (eds), Health and Human Rights in a Changing World (Abingdon: Routledge, 2013) 341, p. 345.

48 Nelson, Law, Policy, p. 52.

49 An overview of the theories on human rights is given in F. Mégret, 'International human rights law theory', in A. Orakhelashvili, Research Handbook on the Theory and History of International Law (Cheltenham: Elgar, 2011) 199. See also (non-exhaustive list), between law, philosophy and history, B. Bourgeois, Philosophie et droits de l'homme: de Kant à Marx (Paris: Presses Universitaires de France, 1990); C. Corradetti (ed.), Philosophical Dimensions of Human Rights (Dordrecht: Springer, 2012); M. Boylan, Natural Human Rights (Cambridge: Cambridge University Press, 2014); O. De Schutter, International Human Rights Law (Cambridge: Cambridge University Press, 2nd edn, 2014); C. Focarelli, La persona umana nel diritto internazionale (Bologna: Mulino, 2013); R. Cruft, S.M. Liao and M. Renzo, Philosophical Foundations of Human Rights (Oxford: Oxford University Press, 2015); D. and E. Lee, Human Rights and the Ethics of Globalization (Cambridge: Cambridge University Press, 2010); J. Donnelly, Universal Human Rights in Theory and Practice (Ithaca, NY and London: Cornell University Press, 2013); A. Cassese, I diritti umani oggi (Roma: Laterza, 6th edn, 2019); S. Besson, 'Legal human rights theory', in K. LippertRasmussen, K. Brownlee and D. Coady (eds), A Companion to Applied Philosophy 
(Hoboken, NJ: Wiley-Blackwell, 2017) 328; S. Fredman, Comparative Human Rights Law (Oxford: Oxford University Press, 2018); S. Besson, 'Justifications', in Moeckli et al., International Human Rights Law, 22. See the critical perspective of E. Posner, The Twilight of Human Rights Law (Oxford: Oxford University Press, 2014).

50 See also A. Cassese, I diritti umani oggi (Roma: Laterza, 1st edn, 2005), p. 70, who argues that it is necessary to reconcile universalism with cultural pluralism, and M.B. Dembour, 'Critiques', in Moeckli et al., International Human Rights Law, 41, p. 50.

51 A. Sen, 'Human rights and Asian values', 1997 lecture, available at www.carnegiecouncil.org/publications/archive/morgenthau/254.

52 See, inter alia, J. Donnelly, 'The relative universality of human rights', Human Rights Quarterly 29 (2007) 281, E. Brems, 'Reconciling universality and diversity in international human rights law', in A. Sajó, Human Rights with Modesty: The Problem of Universalism (The Hague: Brill, 2004) 213; F. Lenzerini, The Culturalization of Human Rights Law (Oxford: Oxford University Press, 2014), chap. 1, and Oxford bibliography on the topic, www.oxfordbibliographies.com/view/document/obo9780199796953/obo-9780199796953-0153.xml (last update 27 June 2017).

53 See, for example, Article 5(b) of the Maputo Protocol. Examples of national legislation are given at www.npwj.org/FGM/Status-african-legislations-FGM.html.

54 S. De Vido, 'Culturally motivated crimes against women in a multicultural Europe. The case of criminalization of FGM in the $2011 \mathrm{CoE}$ Istanbul Convention', in L. Zagato and M. Vecco (eds), Citizens of Europe: Cultures and Rights (Venice: Edizioni Ca' Foscari, 2015) 93.

55 Chinkin and Charlesworth, The Boundaries of International Law, p. 222.

56 GC No. 21, Right of everyone to take part in cultural life (art. 15, para. 1 (a), International Covenant on Economic, Social and Cultural Rights (ICESCR)), 21 December 2009 (ESCR Committee), E/C.12/GC/21, para. 19.

57 See below, in Chapter 1, 'The horizontal, 'interpersonal' dimension: Female genital mutilation/cutting'.

58 See the judgment by the Italian Court of Appeal in Florence, No. 858 of 3 June 2015, which acquitted six defendants who were charged with mass rape of a young woman. The argument supporting the acquittal was based on the contradictory declarations of the woman and on the fact that 'it was a moment of weakness and fragility, which a non-coherent [sic!] life [such] as hers wanted to remove and censor.'

59 A. Byrne, 'Gender challenges for international human rights', in S. Sheeran and Sir Nigel Rodley (eds), Routledge Handbook of International Human Rights Law (London, New York: Routledge, 2013) 615, p. 619.

60 S. Kalantry, Women's Human Rights and Migration: Sex-Selective Abortion Laws in the United States and India (Philadelphia: Pennsylvania University Press, 2017).

61 With regard to marital rape, see K. Yllö and M.G. Torres (eds), Marital Rape: Consent, Marriage and Social Change in Global Context (Oxford: Oxford University Press, 2016).

62 J. Hua, Trafficking Women's Human Rights (Minneapolis: University of Minnesota Press, 2011), p. 11.

63 D. Otto, 'Gender and sexual diversity: a question of humanity?' Melbourne Journal of International Law 17 (2016) 477, p. 484.

64 J.E. Bond, 'International intersectionality: a theoretical and pragmatic exploration of women's international human rights law', Emory Law Journal 52 (2003) 71, p. 72. 
65 D. Otto, 'International human rights law: towards rethinking sex/gender. Dualism and asymmetry', in M. Davies and V. Munzo (eds), A Research Companion in Feminist Legal Theory (London: Ashgate, 2013), p. 211. See also D. Otto (ed.), Queering International Law. Possibilities, Alliances, Complicities, Risks (London: Routledge, 2017).

66 Otto, 'Women's rights', p. 311.

67 Zeus felt in love with Europa, and transformed himself into a bull in order to approach the woman and abduct her. The story is taken from Ovid's Metamorphoses and has been depicted by Rubens in his famous oil on panel The Rape of Europa (1636-7).

68 L. Edelstein, 'The genuine works of Hippocrates', Bulletin of the History of Medicine 7 (1939), reproduced in O. and C.L. Temkin (eds), Ancient Medicine: Selected Papers of Ludwig Edelstein (Baltimore, MD: The Johns Hopkins Press, 1967), p. 133.

69 T. Koch, 'The Hippocratic thorn in bioethics' hide: cults, sects, and strangeness', Journal of Medicine and Philosophy 39 (2014) 75, p. 77.

70 S.A. Leavy, The Psychoanalytic Dialogue (New Haven, CT: Yale University Press, 1980), p. 8.

71 See 'Plato's ethics: an overview', in Stanford Encyclopedia of Philosophy available at http://plato.stanford.edu/entries/plato-ethics/ (last accessed on 1 October 2019).

72 Oxford Dictionaries, available at https://en.oxforddictionaries.com/definition/diagnosis (last accessed on 1 June 2019).

73 K. Sadegh-Zadeh, 'The logic of diagnosis', in F. Gifford (ed.), Philosophy of Medicine (Oxford: Elsevier, 2011), p. 357.

74 Sadegh-Zadeh, 'Logic of diagnosis'.

75 L. Edelstein, 'Hippocratic prognosis', chap. 11 of Peri aeron und die Sammlung der hippokratischen Schriften (Berlin: Weidmannsche Buchhandlung, 1931), reproduced in Temkin and Temkin, Ancient Medicine, p. 69.

76 Edelstein, 'Hippocratic prognosis'.

77 U. Galimberti, Psiche e techne (Milan: Feltrinelli, 2004), p. 259.

78 M. Nussbaum, The Therapy of Desire (Princeton, NJ: Princeton University Press, 2009), p. 28.

79 Nussbaum, Therapy of Desire, pp. 28-9.

80 J. Galtung, Peace by Peaceful Means (London: Sage, 1996).

81 Galtung, Peace by Peaceful Means, p. 26.

82 Galtung, Peace by Peaceful Means, p. 27.

83 WHO, 'Violence against women: an urgent public health priority', Bulletin of the World Health Organization 89 (2011) 2.

84 GC No. 22, para. 49. 